\title{
Reviews
}

\section{Antonio Ballesteros, Narciso y el doble en la literatura fantástica victoriana. Colección Monografías. Cuenca: Ediciones de la Universidad de Castilla-La Mancha, 1998.}

This work may be situated within the renewed interest in 19thc century British literature, particularly in the fantastic fiction produced during that period, shown lately by contemporary literary scholars. Nineteenth century British literature, and fiction most particularly, has been reread and revaluated in the last few decades from a plurality of critical perspectives, which has encouraged its study even further among the different specialists in the field. This book by Antonio Ballesteros may be read as one of these recent critical contributions to the rediscovery of nineteenth century fantastic fiction. The author studies the prevalence of the myth of Narcissus in Victorian literature, especially in fiction, arguing that it is precisely in fiction where the themes of narcissism and duality have been more widely explored. He also vindicates fiction as the most revolutionary and representative genre in a consideration of fantastic literature.

The starting point for this exhaustive study is the consideration of duality (alter ego) as an extension of narcissism. The work is structured into two clearly separated parts. In the first one, the author analyses in a detailed manner the origins and sources of the myth of Narcissus since the Classic Age, with special emphasis drawn to its relevance in English literature from its origins to the second half of the nineteenth century. The second part of the work concentrates in the study of a selection of Victorian literary works, where the author detects the presence of the myth of Narcisus and the theme of duality. He justifies the inclusion in his study of Mary Shelley's Frankenstein here as the epitome of the gothic novel and starting point for the modern science fiction novel. He also underlines the relevance of this novel in later literature, particularly in the area of fantastic literature.

The work starts by making a number of necessary considerations as to the nature of myth, argument and motif, from which the author moves on to the myth and argument of Narcisus and its projection into the motif of duality (alter ego). He departs from Ruiz de Elvira's (1984) definition of myth. Ruiz de Elvira distinguishes a trilogy of essential elements in the concept of myth: uncertainty or improbability, pretension of veracity and tradition. Ballesteros explores the presence of duality (the alter ego motif) in the literature after the Enlightenment and its relation to the upsurge of fantastic literature. He considers not only the literary but also the ideological and socio-historical causes for this sudden flourishment. This is the prologue to his consideration of the presence of the myth of Narcissus in English literature. Ballesteros argues that Narcissus as such is rarely present in English literature, but that instead the motif of the alter ego, of duality, appears, which he relates to the development and success of nineteenth century fantastic literature. In this connection, he vindicates fantastic literature as "the alter ego" of the realist canon, arguing that nineteenth century fantastic literature in 
many ways complements and subverts the canon. Ballesteros identifies one of the essential motifs of fantastic literature precisely as that of duality, of the alter ego. Fantastic literature is seen to reflect the ideological preoccupation for the complex dual nature of the human being, which comes to the fore with the industrial revolution. Literature is understood as the artistic double of reality, and Victorian reality as context of duality itself, where London is used as illustrative example -the author makes a point here of the impact of Charles Darwin's The Origin of Species, published in 1859. The next step in the construction of the central thesis of this critical work is a comparison between (i) the relation between fantastic literature and duality and (ii) the relation between the first (I) and second (you) persons. Fantastic literature is seen as exploring the relations between $I$ and you, $I$ and what is not $I$ : the other. The author outlines a process from being seen as independent and different beings (where you, or not-I, is external to I) to being seen as inseparable, as part of the same being. He argues that we may trace this evolution in the texts chosen as sample.

From this moment, the literary sources of the myth of Narcissus and its presence in English literature are deeply considered, the book concentrating wisely on those sources of relevance for the study which is going to be carried out later on. Two classic sources are studied in detail: Ovid's and Pausanias's, though it is recognized that Ovid's is without doubt the most influential source. Ovid's version is analysed in detail, offering the reader also different readings of it. The author also reviews other Classic and Medieval sources which he considers of relevance, basing his study particularly on the works of Louise Vige (1967) and Yolanda Ruiz Esteban (1989). It is interesting to point out here that he includes later an extensive bibliography with a list of significant sources as well as a classification of critical works which study these sources. Finally, the author pauses for a consideration of Pausanias's version of the myth, to show how he sometimes adopts an ironical positioning towards Ovid's version. Pausanias holds what the author describes as a rationalist position according to which Narcisus has a twin sister with whom he falls wildly in love. At his sister's death, his self-image reflected in the water appears as substitute for the lost sister. Duality here is placed around incest. The author then explores other variations on this theme, offering the reader a very extensive panoramic vision of the Narcissus myth and its main variations. From here, Ballesteros explores the ways in which the myth of Narcisus has been dealt with in English literarure prior to the nineteenth century. He argues that, before the nineteenth century, the myth of Narcisus is always understood as one of Classical Antiquity and particularly Ovid's legacy, and as such he is referred to in an explicit and direct manner. However, from the nineteenth century on, this source undergoes new mythical and thematic variations and additions which make the referential universe more and more complex. Thus, for example, the romantic poet believes the illusion that he is himself Narcissus, which ultimately concludes in a pretended subjectivity. In a way, the character of Narcissus is slowly and progressively freed from the Ovidian frame, at the same time as it loses its traditional moralizing interpretations. An exhaustive survey of the presence of Narcisus in English literature prior to the nineteenth century follows, covering from the Middle Ages to the Enlightenment and Romanticism. 
With all these preliminaries in mind, the second part of this work concentrates around the study of the theme of duality, as extension of the myth of Narcisus, in a selection of works considered by the author to be representative of Victorian literature. The motif of duality (alter ego) is affirmed over other motifs in the literary argument of Narcisus. The author explores the theme of duality in Mary Shelley's Frankenstein; Emily Brontë's Wuthering Heights; Charlotte Brontë's Jane Eyre; Lewis Carroll's Alice Through the Looking-Glass; R.L. Stevenson's Dr. Jekyll and Mr. Hyde; Oscar Wilde's The Picture of Dorian Gray; Abraham Stoker's Dracula; H.G. Wells's The Invisible Man and James Barrie's Peter Pan. The final conclusion is that British literature of the second half of the nineteenth century is the prelude to psychoanalysis in so far as psychoanalysis is going to systematize the human preoccupation for "its other" (the duality analysed in the works selected) in what will become the subconscious. Finally, the reader will find an exhaustive bibliographical section organized in parts according to the different texts under consideration and offering a plurality of readings on these same texts.

Ana Moya

Rodríguez Álvarez, Alicia. Documentos notariales vernáculos del condado de Durham (siglo XV): Estudio y edición. Córdoba: Servicio de Publicaciones de la Universidad de Córdoba y Servicio de Publicaciones de la Universidad de Las Palmas de Gran Canaria, 1997, 253 pp.

It is only within the last decades that there is a renewed interest in performing translations and studies of mediaeval English texts, others than literary. This interest could be a response to a great concern for the generally neglected study of the history of English from other non-literary perspectives that may account for specific phenomena not yet discussed in detail by specialists. In this context, the work Documentos notariales vernáculos del condado de Durham (siglo XV): Estudio $y$ edición (henceforth Documentos notariales) emerges bringing new information about late mediaeval English legal text language and structure.

Rodríguez's Documentos notariales is divided into four main parts covering a great deal of what has been said about mediaeval English legal language and texts: Los documentos, Los escribanos, Los textos, and Edición. The book also comprises an Introducción, Glosario de términos y expresiones legales, Glosario de medidas de superficie, tipos de terrenos y divisiones administrativas, Índice de nombres propios, Índice de topónimos, Mapa del condado de Durham, Índice de comienzos de oraciones, Bibliografia and Figuras.

In part one Los documentos, Rodríguez Álvarez describes not only the physical side of the documents, but also their contents, what serves as main division to her material. The total amounts to the impressive number of 57, some of them not found in the Linguistic Atlas of Late Mediaeval English (1986) and whose data are included in this book for the first time. In this part, the reader is also given some information concerning 
the English legal system of the time, and, more specifically, the legal instruments edited in this work in order to familiarise him/her with their contents. In addition, details regarding the seals attached to the documents are also presented. The author offers under Figures drawings intended for illustration of this part.

The importance of literacy and education connects with the issue of bureaucratic documents, and the need to preserve possessions in written form what, in the case of the documents studied in this book, was generally a task which the population normally required from official scribes and from those monks who had training in a scriptorium. In the second part, the author analyses the question of literacy and she provides a description of those mediaeval men in charge of producing written legal documents in the county of Durham, hence outlining the academic profiles of the scribes, clergy or layman, perfectly aware of the power of the written word to secure their possessions. The transition to the Englishing of legal documents is explained, in this second part, in terms of unsufficient training in Latin. In this sense, those who did not attempt higher academic courses after school had a very elementary knowledge of that classical language.

In part number three, a study of the textual analysis of the legal documents presented here along with the language that characterises this type of writing is performed. Firstly, the author outlines and describes the diplomatic composition of texts. Secondly, recurrent grammatical structures and formulae in the texts are analysed. Likewise, Rodríguez Álvarez suggests the association of certain formulae and expressions with particular sections within the legal document. Finally, the author concentrates on the punctuation displayed to mark division. On many occassions, as she explains, this sentence division is not only a question of the unreliable mediaeval punctuation signs, but of certain expressions and clichés that might warn readers of the beginning of another sentence unit.

The study of punctuation in mediaeval manuscripts is one of the main achievements of Rodríguez Álvarez who proves the existence of a sort of regularity in the use of punctuation conventions against the view of some critics for whom the role of punctuation in mediaeval texts "parecía inexistente" (p. 134).

In part four, the editorial method for the transcription is presented, and then the edition of hitherto unpublished texts are given. Each text is preceded by specific data related to that document: place and document signature, date, type of document and the contents, measure, ink colour, condition of the document, and further information related to the document which differs from one text to another.

In order to help the reader to understand the texts, a number of glossaries which I have mentioned above are included at the end of the book together with a map of the county of Durham where all the places mentioned in the documents are indicated. The entries in the glossaries are followed by the number of the documents where they are contained in brackets, and, in the case of the Glosario de terminos y expresiones legales, the number of the line is also offered.

In conclusion, there is no doubt that Rodríguez Álvarez offers a serious work and rich in detail, and I have no reservations to regard the book as highly commendable.Yet, it is still to be done a comparison of the language these texts display with London 
Chancery legal documents in order to see the degree of standardisation they present. All in all, Documentos notariales reads very well, and is absolutely reader-friendly. It stands as an important contribution for historical studies of English, and the texts presented here may be used for further diachronic studies of the English language.

Francisco Alonso Almeida

\section{Paul Tench (1996). The Intonation Systems of English. New York: Cassell.160 pp.}

It is only within the last 30 years that the study of suprasegmental phenomena has begun to flourish. This may be due to technological advances that have helped researchers in the storing and analysis of intonational data. In this context, the importance of Tench's book relies on the fact that it emerges at a time when there is a great need for a comprehensive study that surveys the most relevant descriptions of intonation.

Another advantage of Tench's book is that, throughout its six chapters, it instils the reader with the idea that the function and description of intonation are a matter for linguistic analysis, since intonation can be described in terms of a set of contrasts. This approach departs significantly from the view widely held among students and some scholars that intonation has a blurred and shapeless identity.

The language used by Tench is largely straightforward, and generally accessible to the novice reader. The book reads very well and may be described as user-friendly.

I begin here by describing the book's layout, and then go on to comment on specific aspects of the text, in an attempt to assess the extent to which the book succeeds in achieving the goal (given below) that the author sets out in the introduction:

This book is intended to introduce to language students and teachers a description of English intonation that will take into account the actual nature of intonation and its functions in spoken language (p.2).

The Intonation Systems of English (henceforth, TISE) consists of a Preface, an Acknowledgement List, followed by six chapters, a Reference Section, and an Index in a total of 160 pages. Chapter 1 offers an introduction to the general field of intonation. Chapters 2, 3 and 4 present the three major components, respectively, of the system put forward by Halliday in his 1967 book titled Intonation and Grammar in British English, which is published by Mouton (The Hague): tonality, tonicity and tone. In chapter 5, Tench analyses the nature of tone in greater detail. Chapter 6 closes the discussion firstly by presenting an outline of the main models of communication included in the literature, and then by showing how intonation participates in the process of communication. Excepting chapter 6, all chapters end with a list of short notes. There is a short practical exercise towards the end of chapter 3, and several exercises are scattered throughout the text. Otherwise, the book lacks any kind of formal exercises. 
At the beginning of chapter 1, Tench makes reference to tone languages. I suggest that such a reference could prove too advanced for the novice reader at this stage, since he/she still suffers from a lack of background knowledge required to identify such languages.

Later in the same chapter (\$3), the reader is introduced to the internal structure of the intonation unit. The description of such a structure is both too advanced for the novice reader and too simplistic for the knowledgeable reader. The former would need to be familiar with the notions represented by terms such as pre-head, head, and nucleus. In addition, he/she is expected to have some understanding of the notion of feet. By contrast, the knowledgeable reader is left with a sense of emptiness, since he/she is offered only an introduction to the controversial issue of the identification of the internal structure of the intonation unit.

A possible way to strike a balance between these two extremes set by beginners and advanced readers may be to add some information about the strategies used for the identification of the internal structure of the intonation unit. In the case of advanced readers, the addition of an endnote may prove extremely useful, pointing out the controversy highlighted earlier and indicating further reading.

In chapter 3, after describing what is new information and given information in an utterance, Tench immediately introduces the distinction between broad focus and narrow focus; however, a logical connection between these terms remains unclear.

Another point to consider in this chapter relates to Tench's remark on page 68: 'Marked tonicity indicates new information that is either grammatical or non-final.' (p68). This claim is inaccurate, since marked tonicity (or narrow focus) can indicate old information that is lexical, not only 'grammatical or non-final'.

At the beginning of chapter 4, Tench's strategy for describing primary and secondary tones falls somewhere short of satisfactory. He describes them initially in terms of their forms (p.73), and then later (p.74) in terms of their function. Given the fact that the formal differences among such tones are frequently unclear, it would seem preferable to justify their classincation primarily from the point of view of their function, rather than vice versa.

In my view, Tench's proposal for a lexicon of attitudinal meanings in chapter 5 offers no significant improvement over earlier attempts, largely because there still remains a certain degree of arbitrariness in the set of terms that he proposes.

A noticeable shortcoming of chapter 6 is the author's failure to make reference to relevant work on the role that intonation plays in a model of communication - for instance, Gussenhoven's book On the Grammar and Semantics of Sentence Accents published in 1983 by Foris Publications, (Dordrecht). It would be prudent to incorporate such references into future editions of TISE.

In conclusion, there is no doubt that Tench offers a serious work that is rich in detail. However, if the book is intended as a textbook, then the omission of further exercises is a serious one. Besides, an audio tape including the examples presented in the text is absolutely essential. In addition to this, the description of some pitch movements could very well be supported by a graphic display of fundamental frequency traces. 
Despite this lack of practical material, the book shows many positive aspects, including a clear organisation of its chapters and the fact that its syntax lies within easy reach of undergraduate students. Nevertheless, while it indeed stands as a valuable contribution to scholarship, it may not lend itself well to the requirements of a basic course text.

My reservations regarding certain aspects of Tench's layout of the book should not be taken as a lack of appreciation for the book as a whole. I consider his treatment of intonation as a linguistic matter a serious contribution to the student's understanding of English intonation. What also deserves praise is the richness of his examples used to illustrate various issues, together with their effectiveness in illustrating those particular issues.

Mercedes Cabrera-Abreu

\section{Ania Loomba. Colonialism/Postcolonialism.London:Routledge, 1998, xviii +289 pp.}

In the New Critical Idiom series, recently inaugurated by Routledge with the aim of providing introductory texts on contemporary critical theories, colonial and postcolonial discourse theories were a "must" that has just been satisfied with Loomba's book. This book is published at a time when the full frenzy of postcolonial studies holds sway, but when postcolonial theory is also facing scathing critiques from several sectors: "The "field," indeed, "is as beleaguered as it is fashionable" (xii).

The book starts by defining the main terms discussed, that is, colonialism, imperialism, neo-colonialism and postcolonialism. It then goes on to describe the several and often divergent views on the colonial process and on ideology in general (although it is impossible to be totally comprehensive, apart from the important works by Gramsci, Althusser and Foucault, the inclusion of Jameson's application of ideology to narrative in The Political Unconscious would have been pertinent here). Debates on ideology, language and subject formation focus on the deep interconnection between reality and their representation, challenging "any rigid demarcation of event and representation, history and text" (37), although the "exhorbitation of discourse" to the detriment of material processes is also severely criticised (96-97).

The second chapter pays further attention to the intersections of postcolonial theory with other contemporary discourses on class, gender, race, self, etc. Loomba succeeds in contextualising the postcolonial discourse, by interrelating it with concurrent movements, discourses and theories, most prominently Marxism, feminism, psychoanalysis, poststructuralism and postmodernism. In doing so, she has intelligently paused to discuss key figures such as Gramsci, Foucault, Fanon, Spivak, Bhaba and other critics, integrating them in the exploration of current debates, so that they do not fracture the narration.

After noting the destabilising nature of hybridity or "mestizaje," Loomba launches the third and last chapter, where the issues of nationalism and pan-nationalism are taken up, as well as the Spivakian question of whether the subaltern can "speak" and offer any active resistance. Ania Loomba arrives at the insightful corollary that nationalism and pan- 
nationalism, hybridity and authenticity are never mutual neat inverses. Instead of a dichotomic framework in thinking about "nation," the author invokes Cabral's theory that a nation is always in flux and extends it by stating that "nation," Anderson's "imagined community," has to be re-imagined again and again in order to survive and be effective. In this section, there lingers some fear of drawing parallelisms to the instances of black and other "ethnic" nationalisms in the United States which would help illustrate Loomba's points about nation-formation and nationalist sentiment, especially the ways in which these are reflected in/created by literature and the conflicts between feminist and nationalist agendas, so clear in Asian American or African American studies.

The last section of this chapter tackles the tensions between postcolonialism and postmodernism, which are reciprocally altered and reorganised as a consequence of their interaction. The philosophical scepticism that seems to emanate from poststructuralist theorists, especially Foucault and Derrida's deconstruction, threatens "the very possibility of human understanding" (42). Loomba warns us against the attendant, concomitant depoliticisation of postcolonial studies and argues instead for the necessary counteraction of highly politicised theories that aim at claiming hitherto marginal voices of resistance. This argument is only exemplified in passing (247-48), but it would deserve some elaboration and illustration, since those communities who have just emerged from colonialism and marginalisation (be it "ethnic minorities," women, lower castes, colonised peoples, etc.) entertain reasonable suspicions of the immobilising, depoliticising effects of bracketing categories, especially "identity." Before acquiring the "subjecthood" that is to be deconstructed, these "ex-objects" of colonisation, exploitation and devious gaze find themselves in the position of de-centred non-entities, without ever having reached the status of "subjects."

Daunting though the critical jargon may seem to any person wishing to approach colonial and postcolonial discourse theories, it is nonetheless the author's intention to make it accessible to common readers. From the beginning, Ania Loomba sets out to employ a "user-friendly" language and is at pains to avoid being obscure. Fortunately for the profane and soothingly for the initiate, only a few cryptic passages and terms have percolated and sedimented in this book. More often than not, the author succeeds in making a point without letting it be engulfed in the tempting web of philosophical disquisitions so dear to deconstructionists and postcolonial theorists. In trying to offer a clear and concise account of such a complex phenomenon, Loomba runs the risk of occasional oversimplification (as when, on page 253 , she incorrectly assumes that such a nuanced term as "catachresis" can be dealt with with just a reductive synonym, "transformation"). She herself foresees this risk when she announces in her preface that "there is always a certain amount of reduction in any attempt to simplify, schematise or summarise complex debates and histories, and the study of colonialism is especially vulnerable to such problems on account of colonialism's heterogeneous practices and impact over the last four centuries" (xiii).

The main objections to the book lie precisely in that excessively ambitious scope, which makes the book dense and the reading slow. By trying to adhere to interdisciplinarity, thus offering us a faithful rendition of the state of the question, since interdisciplinarity is inherent in postcolonial studies, on some occasions she does not 
provide enough literary illustrations or confines literature to certain subchapters when it should permeate the whole book.

There are also some important lacks in the content of the book: such productive intersections as those between postcolonial studies and Bakhtin's theories of dialogism and the carnivalesque are missing, as are the emerging and ever-growing critical corpus on internal colonialism (born in the US, but applicable and applied in other "settler colonies," postcolonial territories and metropolis), or even the diasporic condition, mentioned $(175-76,210)$ but not sufficiently dwelt on.

There are also some understandable flaws such as her avowed preference for matters familiar to her, that is, Indian issues and examples, which she justifies in the preface on the highly plausible grounds that "one's own disciplinary training or identity is bound to shape one's knowledge of the field" (xvi). However, Loomba harps on and resorts all too often to the Indian practice of widow immolation or sati. Other instances of excessive reiteration are the paragraphs on cannibalism (71-74, 58-59), Shakespeare's influence ( 90 , $189)$ and even one of Bhaba's quotes, that appears twice $(146,177)$. Some bibliographic lacks and slips can also be glimpsed, especially the absence of The Empire Writes Back, by Ashcroft, Griffiths and Tiffin, a landmark in making postcolonial theory accessible to the common reader. Apart from the unavoidable misprints, there are some formal deficiencies that can be easily rectified, such as the lack of pagination in the bibliographic entries of some key articles, e.g. Hulme's. Moreover, sections within subchapters are not indicated in the list of contents, whereas they should have been included.

Despite these few shortcomings, the book abounds in good insights and apt introductions to rather complex debates. One such instance is the author's use of Vaughan's critique to comment on Said's fundamental aporia: by "denying the possibility of any alternative description of "the Orient" outside the texts of Orientalism, and, consequently, "any agency on the part of the colonised", he is trapped within the same frame he was dismantling and his political commitment is belied by his philosophical premises (49-50). Throughout the book, Loomba has been successful in weaving "the general and the particular" (xiv), keeping the difficult balance and compromise between heterogeneity and homogeneity, between the necessary generalisations and the insistence on a diversity to which no universalising tendency should blind us. The author has also offered interesting analogies of sexual and colonial (and, to a lesser extent, class and caste) structures of oppression, connivance and resistance (72ff, 106-109, 151-52, 159-64), while insisting on the need to go beyond binary antinomic structures, beyond merely reversing the hierarchical dichotomy. Instead she proposes an integral act of deconstruction, aiming at a dialogic, pluralistic approach to reality.

The best tribute we can pay the author is to admit that her ambitious account of "the major debates and issues" in postcolonial studies has indeed fulfilled her main objective, "to stimulate and enable its readers to explore, and to critique, further afield" (xviii). 


\section{An early Spanish version of Virginia Woolf's "Time Passes".}

The publication history of Virginia Woolf's To the Lighthouse has always received special attention due to the author's decision to publish the central part, "Times Passes", in French translation in 1926, a year before the complete novel appeared in English. Since then there have been many translations of this text, as the excellent fourth edition of B. J. Kirkpatrick's Bibliography of Virginia Woolf (1997) shows. According to this bibliography, the first Spanish translation of "Time Passes" was published in Sur (Buenos Aires, Argentina) in 1938 under the title "Pasa el tiempo". The entry for this item (D190.1) informs us that the translation was "presumably" made by Antonio Marichalar, the translator of the first edition of To the Lighthouse in Spanish (Buenos Aires, 1938). After reading both texts, there is no doubt that Marichalar is the author of that translation of "Time Passes". However, this is not the first rendering of the piece into Spanish. An earlier version of "Time Passes" was published under the title "El tiempo pasa" in Revista de Occidente, Madrid, Vol. 31, No. 93, marzo 1931, pp. 283-97. Although the translator's name is not given, this early text is very different from Marichalar's, and three complete sections are missing (1st, 5th and 10th). It is a suggestive version which predates the Argentinian article by seven years and also comes before the first known text by Woolf in Spanish, which was thought to be Jorge Luis Borges's translation of A Room of One's Own, published in a series of articles in Sur (Buenos Aires, 1935-6). 